\title{
Corporate Tax Integration in Light of Falling Corporate Tax Rates: Using the 1803 British System for Withholding Taxes on Corporate Income as a Model
}

\author{
Raymond L. Richman ${ }^{1}$, Jesse T. Richman ${ }^{2}$ \& Howard B. Richman ${ }^{3}$ \\ ${ }^{1}$ Professor Emeritus, Graduate School of Public and International Affairs, University of Pittsburgh, Pittsburgh, \\ PA, USA \\ ${ }^{2}$ Department of Political Science, Geography, and International Studies, Old Dominion University, Norfolk, VA, \\ USA \\ ${ }^{3}$ Research Associate, Ideal Taxes Association, Pittsburgh, PA, USA \\ Correspondence: Jesse Richman, Department of Political Science and Geography, BAL 7000, Old Dominion \\ University, Norfolk VA 23529, USA. Tel. 757-683-3853. E-mail: jrichman@ odu.edu
}

Received: September 17, 2020

Accepted: October 24, $2020 \quad$ Online Published: November 5, 2020

doi:10.5539/ijef.v12n12p36

URL: https://doi.org/10.5539/ijef.v12n12p36

\begin{abstract}
Tax competition has morphed the corporate tax into a source-based tax with falling rates. Past proposals to integrate corporate taxes with the residence-based personal income tax were rejected because of revenue loss and poorly designed alternatives, but in light of falling tax rates and revenues, integration has become viable. An updated version of the simple and practical 1803 British system would impute corporate income to shareholders and have corporations withhold taxes paid on that income. It would reduce distortions of the current code, including that between domestic and foreign production, could provide more government revenue, and would be more progressive.
\end{abstract}

Keywords: corporate tax, tax integration, tax competition, tax arbitrage, tax withholding

JEL classification: $\mathrm{H} 21$ efficiency, optimal taxation, $\mathrm{H} 25$ business taxes and subsidies.

\section{Introduction}

As a result of tax competition between countries to attract the direct investment of multinational corporations, the corporate tax has gradually morphed into a tax at source. If the country of residence has a higher corporate tax rate than the country of source, the difference in rates cannot be collected by the country of residence, given that corporations can avoid the increased tax by incorporating abroad (corporate inversions). Those U.S. companies that moved their headquarters abroad between 1994 and 2014 were able to reduce their U.S. tax liability "from an average of 29 percent the year before inversion to an average of 18 percent the year after inversion" (Congressional Budget Office, 2017, p. 1). In order to prevent inversions, governments have been forced to relinquish tax claims for the difference between their own corporate tax rate and lower corporate tax rates abroad either by deferring payment of taxes on foreign income or by moving to territorial tax systems.

Also, partly as a result of tax competition (Zudrow \& Mieszkowski, 1986; Genschel \& Schwarz, 2011), countries have halved their corporate tax rates over the last four decades, as shown in Figure 1. In 1981, the average statutory rate in the OECD countries was 47.8 percent and in 2017 it was just 24.2 percent. (In the U.S., the statutory corporate tax rate fell from 49.7 percent in 1981 to 38.9 percent.in 2017: 35 percent federal, 3.9 percent state on the average). And there was no end in sight to the falling rates. In 2017, the U.S. passed a tax rate reduction that would reduce its statutory federal corporate tax rate to 21 percent in 2018. As Barrios et. al. (2018) note, corporate income taxes are currently a relatively small portion of the overall multi-factor effective tax burden borne by businesses in most OECD countries, with labor, energy, and other taxes composing a much larger share. Plausibly, this shift has contributed to increasing wealth and income inequality (Piketty, 2014, 2020) by reducing taxation of capital income. 


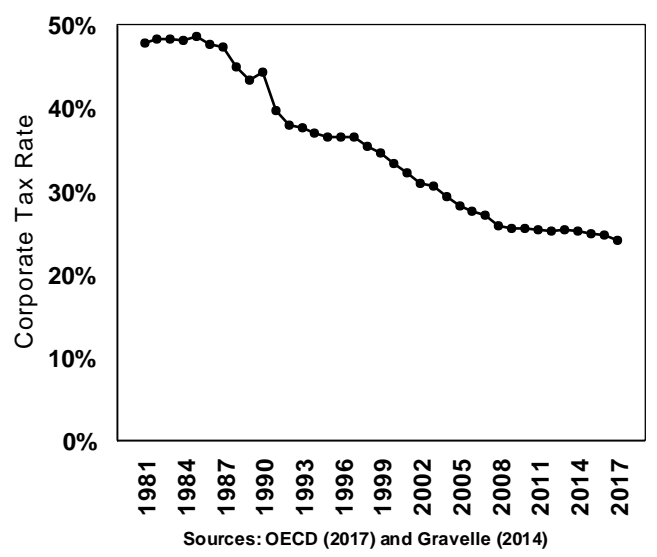

Figure 1. Average unweighted statutory corporate tax rates among OECD countries (Combines rates of central government with rates of sub-central governments)

One solution to tax competition would be to eliminate the corporate tax and instead tax corporate income as the personal income of shareholders, as partnerships are taxed. Doing so would eliminate most of the economic distortions caused by a separate corporate tax (Break, 1969; McLure, 1975; Feldstein \& Frisch, 1977).

Independent studies of tax integration (Feldstein \& Frisch, 1977; Boadway \& Bruce, 1992; Ballard et al., 2014), using three different mathematical models, have compared the full integration of the tax code that we are proposing to partial integration proposals. All three of these studies found the fully integrated system to be superior to partially integrated systems.

But two U.S. government studies predicted substantial loss of revenue when comparing the current system with an overly-complex full integration alternative (U.S. Department of the Treasury, 1992; Gravelle, 2016). Those studies may no longer be relevant. With corporate tax rates falling ever lower, what was once a tax that fell most heavily upon the rich is morphing into a tax break for the rich.

These studies failed to consider the efficient and proven method for integrating the corporate with the personal income tax, incorporated into the British tax code of 1803-1815 and reinvented by Feldstein and Frisch (1977), which taxes corporate income exactly the same way that other business income is taxed. This system would impute corporate income to shareholders and have corporations withhold taxes on that income at some fixed rate to make it administratively simple for the corporation. As we will discuss in more detail below, it solves the practical challenges that have stymied prior proposals (e.g. U.S. Department of the Treasury, 1992; Gravelle, 2016).

In this paper we will discuss the independent studies of tax integration that have found full integration to be an economically preferable alternative. Then we will discuss the two U.S. government studies with overly complicated full integration plans which have found full integration to be an inferior alternative. Finally, we will explain the British tax system of 1803-1815 which taxed individuals on their income from all sources with individuals receiving a credit for the tax paid by corporations, a form of withholding.

\section{Independent Studies of Tax Integration}

Three studies of tax integration have compared the full integration of the tax code that we are proposing to partial integration proposals. Partial integration systems end or reduce the taxation of dividends that is in the personal income tax code but, unlike the system we are proposing, retain the separate corporate tax. All three of these studies found the fully integrated system to be superior to partially integrated systems. And the studies were fully distinct as the authors did not even cite each other's work.

\subsection{Boadway and Bruce Study}

Boadway and Bruce (1992) compared a partial integration "dividend tax credit" system with a full integration or "direct imputation" system in a closed economy and an open economy (an economy with an international sector). The mathematical model that they used assumed that there were only two businesses in the economy, one domestic and one foreign, that they were both financed by equity, and that they both exploited all legal tax arbitrage opportunities. 
They concluded that both the partial and full integration systems can work in a closed economy, but that only the full integration system works well in a small economy that has an international sector. They explained the reason why the partial integration system would not work in a small open economy:

The reason for this is that the dividend tax credit applies against the personal income tax which is typically levied on a residence basis, whereas the corporate income tax is levied de facto on a source basis. (p. 41)

They concluded:

Although the dividend tax credit does achieve some neutralities in the income tax system regarding the financial structure and the organization of the firm, it does not achieve the savings and the investment allocation that corresponds to a perfectly integrated income tax. In the open economy such an outcome can be achieved only by imputing corporate income to shareholders in some way or by converting the corporate income tax to a residence basis (p. 61-62).

They attributed the failure of the partial integration system to the influence of tax arbitrage, which, in turn, is due to the corporate tax being a de facto source-based tax. In other words, the corporate tax does not mesh well with the personal income tax because the corporate tax taxes income on a source basis (tax is paid in the country where the income is earned) while the personal income tax taxes income on a residence basis (tax is paid to the country where the earners of the income reside).

\subsection{Ballard, Fullerton and Shoven Study}

Ballard et al. (2014) updated an earlier study (Fullerton et al., 1981). In both studies, they applied the General Equilibrium Model for Tax Policy Evaluation to compare two systems for fully integrating the corporate income tax (termed "total integration") and to five partial integration "dividend deductibility" systems. They concluded:

Total integration of the personal and corporate income taxes is shown to yield static efficiency gains of about $\$ 4$ billion to $\$ 8$ billion per year, in 1973 dollars. The present value of the dynamic gains range from $\$ 311$ billion to $\$ 695$ billion, depending on the yield-preserving tax. Without indexing, these gains ranged from $\$ 288$ billion to $\$ 474$ billion. The dynamic gains results from the other plans are generally lower, although they exceed $\$ 100$ billion in every case.

The static distributional effects vary among plans. Full integration with multiplicative scaling leads to a progressive change in the distribution of real income over most of the income range. In addition, every class is better off. Dividend deductibility from the personal income tax has a beneficial effect that is more advantageous to high-income groups. (p. 169)

In other words, full integration leads to economic benefits, compared to partial integration, when the goal is achieving economic growth. Also, one of the full integration methods that they studied leads to a more progressive tax system which benefits most of the income range, while the partial integration methods that they studied lead to a less progressive tax system.

\subsection{Feldstein and Frisch Study}

Martin and Daniel (1977) used a tax simulation program to compare a complete integration system that was almost identical with the system we are proposing in this paper with partial integration systems (which retain the separate corporate tax but reduce or eliminate taxation of dividend income through the personal income tax code). They theorized that complete integration would produce a permanent gain in national income by eliminating "four distortions that currently reduce the efficiency of our capital market and our economy" (p. 38). Those distortions were:

1) "The Distortion between Corporate and Noncorporate Activities" (p. 38-39). If investors choose one form of business over another due to differing tax rates, national income is reduced. This distortion is eliminated when corporate income is taxed at the same rate that partnership and sole proprietorship income is taxed.

2) "The Distortion between Future Consumption and Present Consumption" (p. 39). If income earned by savings is taxed at a different rate than other income, the choice between future and present consumption is affected. This distortion is eliminated when business income is taxed at the same rate as other income.

3) "The Distortion between Dividends and Retained Earnings" (p. 39-40.) When corporate income that is distributed as dividends is taxed at a higher rate than corporate income that is retained as earnings, dividends are discouraged. This distortion occurs whenever an extra tax on dividends is applied that is not applied to retained earnings. 
4) "The Distortion between Equity Finance and Debt Finance" (p. 40). This distortion occurs because interest payments are deductible from profits, but dividends are not. This distortion is eliminated whenever an extra tax on dividends is ended.

They concluded that full integration of the corporate tax with the personal income tax code would result in more economic efficiency:

We have argued that either proposal would be desirable because of the favorable effects on the efficiency of the capital markets. Complete integration would have greater benefits than partial integration, particularly with respect to the allocation of consumption over time and of capital between corporate and noncorporate activities. Microeconomic simulations using the TAXSIM model and the 1973 Treasury Tax File show that either form of integration would reduce taxes relatively more for low income individuals and would actually raise taxes for high income individuals. (p. 49)

Currently corporate owners are taxed at the same tax rate whether they are rich or not. In contrast, taxing corporate income through the personal income tax code would utilize the progressivity that is already part of that tax code.

\subsection{Discussion}

As Boadway and Bruce noted, the corporate tax gives corporations tax arbitrage opportunities that they would not have under an integrated tax code. These arbitrage opportunities result from differing corporate tax rates between countries and create a fifth economic distortion, not anticipated by Feldstein and Frisch - the distortion between domestic and foreign production.

Countries have been competing to attract the factories of multinational corporations. Arnold (2006) has found that corporations that compete only against domestic producers are often able to pass the tax forward to consumers but that manufacturers who compete with international competition cannot pass the tax forward (see also Abuselidze, 2012).

As a result, corporations that are more mobile have been seeking lower corporate tax rates, and have even been receiving lower tax rates in countries that have higher statutory tax rates (Hines, 2007) (Note 1). They seek the most profitable investment opportunities across the globe, partly based upon the effective marginal tax rate (Abuselidze 2020, De Mooij \& Ederveen, 2008; Feld \& Hockemeyer, 2011).

It is clear that the separate corporate tax creates a distortion between domestic production and foreign production. Corporations tend to place their factories (or at least their income) in countries where the corporate tax is lower. Also, they avoid or evade paying taxes in high-tax-rate jurisdictions, even when most shareholders are in those jurisdictions, which increases income inequality (Bertotti \& Modanese, 2018). Taxing shareholders through the personal income tax in their country of residence would eliminate this distortion. Shareholders would pay the same tax rate whether the corporate income were earned from factories in the country where the shareholders reside or earned abroad. And given the opportunity to earn income tax refunds on corporate income taxes paid, shareholder interest in corporate tax avoidance could diminish, likely leading to better tax compliance and higher revenues, particularly if withholding rates exceed individual tax rates (Brown et al., 2020, Gokalp et al., 2017).

In this section, we have discussed three studies that have compared full integration of corporate income taxation with partial integration. These studies were fully independent of each other (indeed none of the authors cited the others) and used completely different mathematical models, yet they all came to the conclusion that the economic effects of full integration are superior to the effects of partial integration.

According to Boadway and Bruce, full integration ends the savings and investment allocation problems caused by corporate tax arbitrage opportunities. According to Ballard et al., full integration results in increased economic growth and a more progressive tax system. According to Feldstein and Frisch, full integration ends four economic distortions and makes corporate taxation more progressive.

\section{U.S. Government Studies}

Two U.S. government studies considered the revenue impact of full integration. Both rejected full integration for two reasons: (1) the complexity of the full integration alternatives considered and (2) the revenue loss that would occur.

Both studies considered, as their primary full integration method, the complex full integration system proposed by the Carter Commission in Canada (Musgrave, 1968; Break 1969) which refunded witheld taxes through the capital gains tax code, instead of the simple British withholding system developed in 1803 which refunded taxes withheld through the personal income tax code. 
In order for their system to work, the Carter Commission advocated that the capital gains tax code be simultaneously converted to an accrual system (also called the "mark-to-market" method), which taxes capital gains of corporate shares annually, based upon the change in stock market price. However, an increase in the value of one's capital portfolio is not income. Capital is the source of income. An increase in the value of the source of income represents the value of expected future income. The accrual method of capital gains taxation confuses capital and income and does not appear practical in real-world taxation settings (Note 2), so it is hardly a surprise that it was deemed unworkable.

The U.S. Department of the Treasury (1992) studied four different methods for integrating the individual and corporate tax systems. All were easily rejected:

1) Flat business tax with no deduction of interest. All businesses (including proprietorships and partnerships) would be taxed at a flat rate of 31 percent with no deduction of interest payments.

2) Eliminating the tax on dividends. They proposed keeping the corporate income tax but eliminating the taxation of dividends in the personal income tax code.

3) The Carter-Commission's full integration proposal. This proposal was rejected partly due to "administrative complexities" (p. 27).

4) Their own full integration proposal. They loosely based their own proposal upon the New-Zealand tax system, and then rejected their own idea due to its "complexity in creating an entirely new regime for taxing corporate dividends" (p. 93).

In a Congressional Research Service study, Gravelle (2016) discussed three methods of tax integration drawn from the U.S. Treasury's (1992) study. Gravelle's full integration proposal was essentially the Carter Commission's proposal with its unworkable accrual method of capital gains taxation. Gravelle concluded that the full integration and partial integration proposals could be ruled out due to revenue inadequacy, but that the chief problem with the full integration proposal was the unworkability of accrual taxation of capital gains, because "a major issue with the mark-to-market proposal, one that would be very difficult to overcome, is taxation of income (reflecting capital gains) even though stocks are not sold and income is not realized" (p. 38).

\section{British Tax System of 1803-1815}

The British tax system of 1803-1815 (Bank, 2011, pp. 21-26), under Prime Minister Lord Henry Addington, demonstrates how corporate tax integration can be done without resulting in administrative complexities and without moving to the unworkable accrual method of capital gains taxation. Furthermore, with corporate tax rates falling worldwide, that tax system could result in revenue gains, not revenue losses.

The 1803 system was Britain's third income tax system since 1799 and was created to raise revenue for the Napoleonic Wars. In all three systems, business income earned by corporations, partnerships and proprietorships was taxed as personal income (Note 3). Each iteration solved the problems of the previous iteration without making the tax code more complex.

The main innovation of the second system was a graduated system of taxation. Those with income under $£ 60$ pounds would pay no taxes. Those with incomes between $£ 60$ and $£ 200$ would pay a lower percentage than those with incomes above $£ 200$. The British demonstrated how a graduated income tax system could tax corporate income. This innovation was lost in modern iterations of corporate taxation which tax corporate income through a flat tax.

The main innovation in the third system was the application of tax withholding, a longstanding idea in earlier property and income taxes in Britain, to all wage income and all corporate income. "Addington's reintroduction of the deduction-at-the-source principle was a stroke of genius. The yield of the tax reached, for those times, the fantastic sum of nearly sixteen million pounds per year before the tax was discontinued at the end of the Napoleonic Wars" (Richman, 1957, p. 113). Combined with administrative changes that better aligned the interests of local and national tax authorities, deduction at source reduced opportunities for tax underpayment. More revenue was raised in the third system, compared with the second, even though the top tax rate was halved from 10 percent to 5 percent.

Corporations paid the 5 percent income tax on behalf of their shareholders and credited their shareholders with the income thus paid. Bank explains:

[T] he new act integrated the corporate and individual income taxes under what effectively served as an imputation system. Corporations were subject to a tax on the "amount of the annual profits, and gains" of the company "before any dividend shall have been" paid, effectively amounting to a tax on 
the entire corporate income, rather than on the income other than that set aside for payment of a dividend, as under a dividend deduction scheme. (p. 25)

The British repealed their 1803 income tax system in 1815 as planned, six months after their victory over Napoleon at the Battle of Waterloo. But it was re-instituted with little change when Britain adopted what eventually became a permanent income tax system in 1842 (Bank, p. 28-29) (Note 4).

\subsection{The Withholding Tax Proposal}

The principle of our proposed system is simple: As far as taxes are concerned, corporations would be pass-through entities. Our proposal begins with the "complete integration" system described by Feldstein and Frisch (1977). Here's how they described their system:

Complete integration is equivalent to treating corporations like partnerships. Corporate profits are included in the individual's taxable income, regardless of whether they are paid out as dividends or retained by the corporation. The corporate income tax as such is completely eliminated. Tax credits are also passed through to individuals. (p. 37-38)

Some key elements:

1) They proposed that corporate tax withholding rate remain at the level of the current corporate income tax, so shareholders in high income tax brackets might have additional taxes to pay, while those in lower income tax brackets might be able to "offset other tax liabilities or claim a refund" (p. 38).

2) They proposed that the corporation pay the corporate tax on behalf of non-resident foreign shareholders and pension funds, otherwise the tax would never be paid. This could be done very simply through the tax withholding system if nonresidents and pension funds are simply deemed ineligible for refunds of the tax withheld.

We propose that corporations pay tax at the same fixed rate, such as 21 percent of net earnings, and that all shareholders be credited at the same fixed rate for personal income tax purposes. Tax withheld would be on income earned in the United States times the withholding rate (the statutory corporate tax rate at the time the new system was adopted which would be 21 percent if adopted in the U.S. in 2020). This would apply to all entities owning shares in corporations doing business in the domestic market.

Ownership would be established for tax purposes on specified days, just as it is already established for receipt of corporate dividends. Ownership of corporations for dividend and dividend taxation purposes is a well-known and already-solved problem. A corporate withholding tax system would use the same principle. Whoever receives the corporate dividend could be considered the owner of the corporation for the time between the last dividend and the current dividend for corporations that pay a dividend. In addition, the last day of the tax year would function the same as a dividend date even if no dividends were given on that date. The resulting tax implications would become just another factor influencing the change in stock prices, much as currently seen after a dividend.

This ready solution to partial year ownership under our proposed withholding tax system is in stark contrast to the Carter Commission's complex proposal for crediting the withheld tax under the capital gains tax. When discussing its own version of the Carter Commission's system, the U.S. Treasury (1992) wrote:
Administratively, shareholder allocation integration would require corporations and shareholders to amend governing instruments for outstanding corporate stock to provide for income allocations, would require corporations to maintain capital accounts similar to those used under the partnership rules, and could create significant reporting difficulties for shareholders who sell stock during a year and for corporations that own stock. (p. 27)

Tax withholding automatically avoids these problems with little disruption, since it is already present in the American income tax system.

Every foreign corporation earning income in the U.S. and every domestic corporation in the U.S. would be required to issue withholding statements to its shareholders (Note 5). The corporate withholding statement would include the following information:

1) Income Earned. The total amount of corporate income that had been credited to the shareholder. Where income had been earned abroad and tax on that income paid abroad, that income would be itemized by country on the withholding statement.

2) Tax Withheld. The total amount of tax that had been withheld by the corporation on behalf of the shareholder. Corporations wanting to pay shareholders more than the amount per share required to be 
withheld, in effect a capital contribution, might do so without increasing the personal income tax liability of shareholders.

3) Foreign Tax Credits. Where income had been earned abroad and tax on that income had been paid abroad, taxes paid abroad would be itemized by country on the withholding statement.

Shareholders would use the withholding statement to calculate their tax liability. What would happen next depends upon the nature of the shareholders:

- Corporations. Where domestic corporations are the shareholders, the contents of the received withholding statement would be added in to their own withholding statements to their own shareholders (Note 6). The principle of this provision is that corporations are pass-through entities.

- Non-Taxpaying Entities. When nonprofit corporations, pension funds, defined contribution plans, Roth IRAs, traditional IRAs, nonresident foreigners or foreign corporations are the shareholders, the tax withheld would not be refunded. The principle of this provision is that all income should be taxed.

- Individual Taxpayers. When personal income filers are the shareholders, the information on the withholding statements would be entered into their personal income tax forms. The corporate income would be part of their own personal income. The tax withheld would be a credit for tax that they had already paid. If corporate income had been earned abroad, they would only be liable for tax in excess of the amount already paid on that income to foreign governments. Where they had earned income from foreign corporations, they would be liable for the tax, even if they had not received withholding statements from those foreign corporations (Note 7). The principle of this provision is that taxpayers should be taxed at their graduated individual tax rates in their country of residence under the personal income tax. Obviously, those in tax brackets above the withholding level would have to pay additional tax while those in tax brackets below the withholding rate would receive a credit in determining their personal income tax liability.

- Foreign corporations and foreign entities owning shares in businesses would have to file a return, and pay personal income tax at the top tax bracket of the personal income tax.

The early nineteenth and the twenty first century are separated by an enormous gulf of technological and financial innovation. However, in the U.S. partnerships and S-Corporations are still taxed as pass-through entities, so many of the details have already been worked out in the U.S. tax code. For example, dividends received by shareholders of S-Corporations are already exempt from taxation just as dividends received by shareholders of C-Corporations would be under the new system. The only new provision here is the tax withholding of corporate income. In this section, we have developed details about how that system would work in practice. It would operate in a simple, straightforward, and transparent way that avoids the complexities that have torpedoed some previous proposals for tax integration. Because tax would be withheld on behalf of the owner of every share, taxes up to at-least the current corporate tax rate would be paid on all corporate income even in the face of complex financial structures. Individual owners of corporate stock would pay taxes at the personal tax rate on all of their imputed corporate income.

\subsection{Revenue Impact}

Both of the U.S. government studies partly rejected full integration due to revenue loss. But their revenue estimates might be different if they considered our proposal and the 2018 decline in the statutory U.S. corporate tax rate from 35 percent to 21 percent. Revenue calculations for our proposal are quite complex. They depend upon a multiplicity of factors, including American and international tax rates and the distribution of corporate ownership. The following four factors would increase government revenue:

1) American ownership of foreign corporations. Where an American is in a higher tax bracket than the corporate tax rate in the country of the foreign corporation, the American would owe tax on the difference. In 2015, about 19 percent of the corporate equity owned by Americans was abroad (Rosenthal \& Austin, 2016, p. 931). Currently this difference in tax rates goes untaxed.

2) Corporate income earned abroad. The income earned by American corporations abroad would be taxed under the personal income tax rate after subtracting a credit on income taxes paid to foreign governments whenever the foreign government's tax rate is lower than the personal tax rate of the shareholder. Currently this difference in tax rates goes untaxed.

3) Higher corporate income tax rate for rich. Most of the Americans who own U.S. corporate stock would be in the top personal income tax rate (37 percent in 2018), which is higher than the federal corporate tax rate (21 percent in 2018). Even if the current double-tax on dividend income is included in the calculation, the 
difference could be significant, given that about half of corporate income is not distributed as dividends (Standard \& Poors, 2017).

4) The corporate tax rate may continue to fall. As governments continue to compete for the factories and headquarters of multinational corporations, the corporate tax rate worldwide may continue to fall, which would further accentuate the above factors.

The following two factors would reduce government revenue:

1) Capital gains tax revenue could go down. There would be no change in the rate of capital gains taxation, but stock buybacks would decrease and dividends would increase, and this would tend to slow the rise in stock prices and reduce capital gains tax revenue. However, capital gains are often never realized, and thus never taxed. Gravelle (2016, p. 15) estimates that only about half of capital gains are taxed.

2) Lower corporate income tax rate for the middle class. Middle class Americans who own U.S. corporate stock would pay the tax on corporate income at their personal income tax rate, which, for some, would be lower than the federal corporate tax rate, especially since the double tax on dividend income would be eliminated.

So, four factors would tend to cause tax revenue to increase while two factors would tend to cause tax revenue to decrease. The net effect upon revenue could be calculated for a particular country at a particular time if all of the above factors were known.

\section{Summary}

Integrating the corporate tax with the personal income tax code would reduce five distortions of the current code. The first four were enumerated by Feldstein and Frisch (1977), the fifth is based upon Boadway and Bruce (1992):

1) The distortion between corporate and noncorporate activities.

2) The distortion between future consumption and present consumption.

3) The distortion between dividends and retained earnings.

4) The distortion between equity finance and debt finance.

5) The distortion between domestic production and foreign production.

In addition, taxing corporation income under the personal tax code would make the taxation of corporate income more progressive. Currently shareholders pay a flat tax on corporate income, but when taxed under the personal income tax code, they would pay a graduated tax.

Studies by U.S. government entities (U.S. Department of the Treasury, 1992; Gravelle, 2016) have not led to the implementation of full integration proposals for two reasons which are arguably no longer valid:

1) Impracticable alternatives. These studies considered overly complex and unworkable full integration alternatives. They did not consider the simple and proven British withholding system initiated in 1803.

2) Revenue. As a result of reduced corporate tax rates, outsourcing, and inversions, taxing corporate income through pass-through taxation might not result in revenue loss. Revenue estimates would depend upon a multiplicity of factors, which vary, depending upon current tax rates, both domestic and international, and the distribution of corporate ownership.

The successful British system implemented income tax withholding and applied it to both wage income and corporate income. It produced twice as much revenue as its immediate predecessor, despite cutting the top tax rate in half. It imputed corporate income to shareholders, had corporations withhold taxes paid on that income, and had shareholders pay personal income tax on the income that their corporations had earned. Feldstein and Frisch (1977) reinvented this system and applied it to the modern tax environment. We accept all of their specifications.

There is a general principle here: when it comes to taxes: Simpler is usually better. Three mathematical studies have independently found that full integration is better than a more complex partial integration system which retains the separate corporate tax. Our proposal is simpler than the full integration proposal put forward by Canada's Carter Commission and, as a result, avoids the administrative problems which stymied that proposal.

The corporate tax is broken, as evidenced by falling rates and reduced tax revenue worldwide. It has become a tax at source, in contrast to the personal income tax which remains a tax at residence. Tax competition and tax arbitrage have made collection increasingly difficult. 
The British invented graduated income taxation and tax withholding, and applied both inventions to wage income and to corporate income. The world kept graduated taxation and tax withholding for wage income, but discarded both innovations with regard to the taxation of corporate income. Two of the greatest inventions of income tax history have been lost from corporate taxation. It is time that they be restored.

\section{Acknowledgements}

This research did not receive any specific grant from funding agencies in the public, commercial, or not-for-profit sectors.

\section{References}

Abuselidze, G. (2012). The Influence of Optimal Tax Burden on Economic Activity and Production Capacity. Intellectual Economics, 6(4), 493-503.

Abuselidze, G. (2020). Optimality of Tax Policy on the Basis of Comparative Analysis of Income Taxation. European Journal of Sustainable Development, 9(1), 272. https://doi.org/10.14207/ejsd.2020.v9n1p272

Ballard, C. L., Fullerton, D. Shoven, J. B., \& Whalley, J. (2014). A General Equilibrium Model for Tax Policy Evaluation. Chicago, IL: University of Chicago Press. https://doi.org/10.1086/261506

Bank, S. A. (2011). Anglo-American Corporate Taxation: Tracing the Common Roots of Divergent Approaches. Cambridge, UK: Cambridge University Press. https://doi.org/10.1017/cbo9781139013284

Barrios, S., Nicodème, G., \& Fuentes, A. J. S. (2019). Multi-Factor Effective Corporate Taxation, Firms' MarkUps and Tax Incidence: Evidence from OECD Countries. Fiscal Studies, 39(3), 417-453. https://doi.org/10.1111/j.1475-5890.2017.12153

Bertotti, M. L., \& Modanese, G. (2018). Mathematical models describing the effects of different tax evasion behaviors. J Econ Interact Coord, 13, 351-363. https://doi.org/10.1007/s11403-016-0185-9

Boadway, R., \& Bruce, N. (1992). Problems with Integrating Corporate and Personal Income Taxes in an Open Economy. Journal of Public Economics, 48, 39-66. https://doi.org/10.1016/0047-2727(92)90041-d

Break, G. F. (1969). Integration of the Corporate and Personal Income Taxes. National Tax Journal, 22(1), 39-56.

Brown, R., Lim, Y., \& Evans, C., (2020). The impact of full franking credit refundability on corporate tax avoidance. eJournal of Tax Research, 17(2), 134-16. https://www.proquest.com/docview/2397706021

Congressional Budget Office. (2017). An Analysis of Corporate Inversions. Congressional Budget Office, Washington, DC. https://doi.org/10.2172/10115180

De Mooij, R. A., \& Ederveen, S. (2008). Corporate Tax Elasticities: A Reader's Guide to Empirical Findings. Oxford Review of Economic Policy, 24, 68-97. https://doi.org/10.1093/oxrep/grn033

Feld, L. P., \& Hockemaier, J. H. (2011). FDI and Taxation: A Meta Study. Journal of Economic Surveys, 25(2), 233-272. https://doi.org/10.1111/j.1467-6419.2010.00674.x

Feldstein, M., \& Frisch, D. (1977). Corporate tax integration: The estimated effects on capital accumulation and tax distribution of two integration proposals. National Tax Journal, 30, 37-52.

Fullerton, D., King, A. T., Shoven, J. B., \& Whalley, J. (1981). Corporate tax integration in the United States: A General Equilibrium Approach. The American Economic Review, 71(4), 677-691.

Genschel, P., \& Schwarz, P. (2011). Tax Competition: A Literature Review. Socio-Economic Review, 9(2), 339-370. https://doi.org/10.1093/ser/mwr004

Gokalp, O. N., Lee, S., \& Peng, M. W. (2017). Competition and corporate tax evasion: An institution-based view. Journal of World Business, 52(2), 258-269. https://doi.org/10.1016/j.jwb.2016.12.006.

Gravelle, J. G. (2014). International Corporate Tax Rate Comparisons and Policy Implications. Congressional Research Service, Washington, DC.

Gravelle, J. G. (2016). Corporate Tax Integration and Tax Reform. Congressional Research Service, Washington, DC.

Harberger, A. C. (2006). Corporate Tax Incidence: Reflections on What is Known, Unknown, and Unknowable. Paper presented at a conference on Is It Time For Fundamental Tax Reform: The Known, Unknown, and Unknowable? April, sponsored by James A. Baker III Institute for Public Policy, Rice University, Houston, TX. https://doi.org/10.7551/mitpress/9780262042475.003.0017 
Hines, Jr., \& James, R. (2007). Corporate Taxation and International Competition. In A. J. Auerbach, J. R. Hines, \& S. Joel (Eds.), Taxing Corporate Income in the $21^{\text {st }}$ Century (pp. 268-306). Cambridge University Press, Cambridge, UK. https://doi.org/10.1017/cbo9780511510823.020

Ikenberry, D., Lakonishok, J., \& Vermaelen, T. (1995). Market Underreaction to Open Market Share Repurchases. Journal of Financial Economics, 39, 181-208. https://doi.org/10.1016/0304-405x(95)00826-z

Loretz, S. (2008). Corporate Taxation in the OECD in a Wider Context. Oxford Review of Economic Policy, 24, 639-660. https://doi.org/10.1093/oxrep/grn035

McLure, Jr., \& Charles, E. (1975). Integration of the Personal and Corporate Income Taxes: The Missing Element in Recent Tax Reform Proposals. Harvard Law Review, 88(3), 532-582. https://doi.org/10.2307/1340323

McNally, W. J., Smith, B. F., \& Barnes, T. (2006). The price impacts of open market repurchase trades. Journal of Business, Finance and Accounting, 33, 735-752. https://doi.org/10.1111/j.1468-5957.2006.00618.x

Musgrave, R. A. (1968). The Carter Commission Report. The Canadian Journal of Economics / Revue canadienne d'Economique, 1(1), 159-182. https://doi.org/10.2307/133829

OECD. (2017). Table II. Satutory Corporate Income Tax Rate. Retrieved on November 22, 2017 from http://stats.oecd.org/index.aspx?DataSetCode=TABLE_II1

Piketty, T. (2014). Capital in the Twenty-First Century. Cambridge Massachusetts: The Belknap Press of Harvard University Press. https://doi.org/10.7202/1035112ar

Piketty, T. (2020). Capital and Ideology. Cambridge Massachusetts: The Belknap Press of Harvard University Press. https://doi.org/10.1111/1467-8675.12505

Rasbrant, J. (2013). The Price Impact of Open Market Share Repurchases. Working paper, Uppsala University.

Rosenthal, S. M., \& Austin, L. S. (2016). The Dwindling Taxable Share of U.S. Corporate Stock. Tax Notes, 151, 923-934.

Standard \& Poors. (2017). Retrieved on December 1, 2017 from http://globalindices.standardandpoors.com/documents/additional-material/sp-500-buyback.xlsx

U.S. Department of the Treasury. (1992). Report of the Department of the Treasury on Integration of The Individual and Corporate Tax Systems Taxing Business Income once. U.S, Department of the Treasury, Washington, DC.

U.S. Department of the Treasury. (2016). Average Effective Federal Corporate Tax Rates. U.S Department of the Treasury, Office of Tax Analysis, Washington, DC.

Zodrow, G. R., \& Mieszkowski, P. (1986). Pigou, Tiebout, Property Taxation, and the under provision of local public goods. Journal of Urban Economics, 19(3), 356-370. https://doi.org/10.1016/0094-1190(86)90048-3

\section{Notes}

Note 1. This contention is somewhat supported by a table published by the U.S. Department of the Treasury (2016, p. 2) which shows that from 2007-2011 the average tax rate paid (i.e., dividing the financial statement income by the tax actually remitted) by corporations in the less mobile construction and wholesale-retail sectors was 27 percent, while corporations in the more mobile manufacturing sector paid a lower rate of 22 percent.

Note 2. The one time the accrual method of taxing capital gains was actually tried (the Italian Tax Reform of 1988), it was a disaster (Alworth et al., 2003).

Note 3. Corporations are legal entities that are owned by their shareholders which compete in product markets with partnerships and proprietorships. They are limited liability entities in that, if they go bankrupt, their owners are not liable for further debts owed. But partnerships and proprietorships can also register as limited liability enterprises.

Note 4 . During the $20^{\text {th }}$ Century, the British gradually moved away from full integration, partly with the goal of discouraging dividends in order to encourage retained earnings (Bank, p. 49). After World War II, they even experimented with reduced taxation of retained earnings and increased taxes on dividends in an attempt to further encourage retained earnings and discourage dividends (Bank, pp. 61-65). Then in 1965, they switched to the American system of taxing corporations as if they were separate entities from their owners (Bank, p. 3). The revenue gains associated with such a switch are, we argue, no longer present. 
Note 5. Foreign corporations would include income earned and taxes paid worldwide on the withholding statements. But tax payments on income earned in the United States would only be considered the withheld income of Americans to the extent that shareholders were Americans. To the extent that shareholders were foreign residents or foreign corporations, the amount paid to the U.S. Treasury would be a non-refundable withholding tax.

Note 6. An Internet website, maintained by the U.S. Treasury Department, could assist with the instantaneous transmission of this information between corporations so that withholding statements could be issued to shareholders within a month of the end of the tax year.

Note 7. U.S. tax treaties with other countries should be renegotiated so that foreign corporations provide withholding statements for U.S. residents in return for U.S. corporations providing withholding statements for foreign residents.

\section{Copyrights}

Copyright for this article is retained by the author(s), with first publication rights granted to the journal.

This is an open-access article distributed under the terms and conditions of the Creative Commons Attribution license (http://creativecommons.org/licenses/by/4.0/). 